\title{
Histological Adaptation to Thermal Changes in Gills of Common Carp Fishes Cyprinus carpio L.
}

\author{
Tagrid H. Saber \\ Department of Basic Science \\ College of Dentistry \\ Mosul University
}

(Received 20/9/2010; Accepted 8/11/2010)

\begin{abstract}
Investigations were carried out on the gill tissues of common carp Cyprinus carpio L. exposed to high levels $31^{\circ} \mathrm{C}$, and low levels $18^{\circ} \mathrm{C}$ of temperature for a total period of successive of 10 days. The histological study of the gill sections of this fish species showed marked histological lesions, include hyperplasia and hypertrophy of the respiratory epithelium, bloody congestion with hemorrhage and abundance of mucous substance, this at high temperature, while at low temperature also showed hyperplasia, shrinkage of blood vessels, fusion of secondary lamellae, cellular atrophy, damage and lamellar disorganization. Lesions were comparatively most severity at low temperature.
\end{abstract}

Keywords: Histology, Gills, Thermal Changes, Cyprinus carpio L..

\section{التألم النسجي التغييرات الحراربة في غلاصم السمك كارب الاعتيادي \\ (Cyprinus crpio L.)}

\section{المالخص}

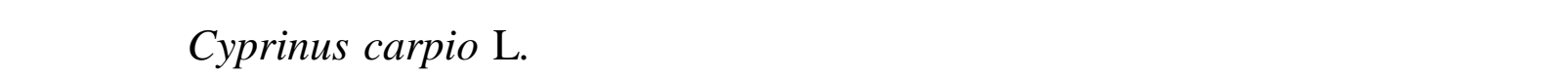

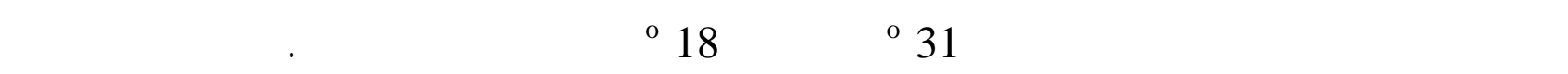

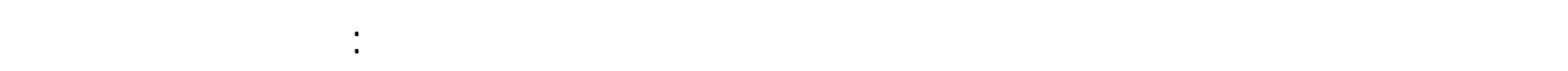

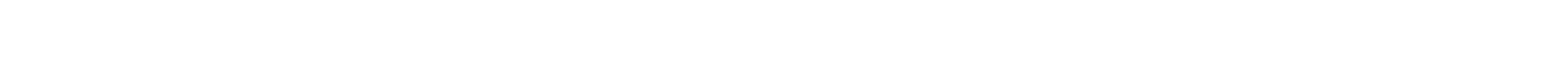

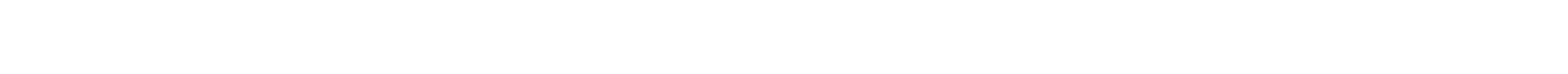

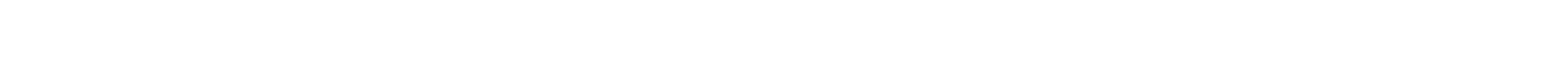
ضمور خلوي، تُطم وعثم انظطلم صفائجي، وكالت الآفت النجية ألثرشدة في حالة الحرارة المنخفضة. الهاملت الدالة: لنسجة ، الغلاصم ، التغيرات الحرارية، لسمك الكارب. 


\section{INTRODUCTION}

The gills, which participate in many important functions in fish, such as respiration, osmoregulation and excretion, remain in close contact with the external environment, and particularly sensitive to changes in the quality of the water, are considered the primary target of the contaminants (Poleksic and Mitrovic-Tutundzic, 1994; Mazon et al., 2002; Fernandes and Mazon, 2003; Ogundiran et al., 2009).

Owing to the direct and continuous contact with aquatic environment, fish gills which are organs for respiratory gas exchange, osmoregulation, excretion of nitrogenous waste products and acid base regulation, are directly affected by contaminants. Fish gill is very sensitive to physical and chemical alterations of the aquatic medium such as: temperature, acidification of the water supply due to acid rain, salts and heavy metals, and to any change in the composition of the environment which is an important indicator of water borne toxicants. Acid and heavy metals pollution has been reported to alter cell structure and induce desquamation to lamellar epithelium and filament epithelium hyperplasia (Leino and McCormick, 1984; Soderberg et al., 1984; Crespo and Sala, 1986; Sinhaseni and Tesprateed, 1987; Nowak, 1992; Risburg and Bastide, 1995; Ayoola, 2008a).

There is a close relationship between gill morphological alteration and stress (Peters and Hong, 1985). Gill morphology has been described as a good indicator of the water quality and the general health condition of cultured fish (Peters et al., 1984). Szakolczai, (1997) studied the histopathological changes induced by environmental stress in common carp Cyprinus carpio, the Japanese colored (carp-Cyprinus), and African cat fish Calarias gariepinus. In all the species treated, it was observed that the goblet cells of the gills and the skin increased in number and there was slight detachment of the epithelium of the secondary lamellae was observed.

Gill epithelium is a major site of gaseous exchange (Korai et al., 2010) and are an important site for disease production, because they are a rich source of blood, an important media for the infectious agents. Sinse gasous exchange takes place through the gills, they may easily become contaminated from external sources (Awal et al., 2001). Sublethal level of detergents have been reported to induce gill damage and impaired active oxygen uptake (Lemke and Mount, 1963) and gill damage in form of hemorrhage has also been observed in Gambusia affinis exposed to Diquat (Tat-Sing et al., 1983).

Coutinho and Gokhale (2000) found epithelial lifting in the gills of carps Cyprinus carpio and tilapias Oreochromis mossambicus exposed to the effluents of a waste water treatment plant. Engelhardt et al., (1981) observed epithelial lifting and lamellar fusion in rainbow trouts Oncorhynchus mykiss exposed to petroleum residues. Similar alterations in the gills have also been reported in the fishes exposed to metals (Oliveira Ribeiro et al., 2000; Cerqueira and Fernandes, 2002 ; Martinez et al., 2004).

Solid et al., (2005) showed that the exposure of gold fish Carrassius auratus, and the crucian carp Carassius carassius to different degrees of temperature $(10,15,20,25)^{\circ} \mathrm{C}$ for one month, induce alteration in form of gills, range consumption of dissolved oxygen in water and concentration of dissolved oxygen in water.

In Iraq Al-Hamdani and Al-Taee (2009) studied the effect of thermal stress on fish Carassius auratus. 
The gills have relatively small number of components: epithelium, endothelium, Pillar cells, fibrous and cartilaginous support stroma, in the primary lamellae, and specialized cells such as eosinophil granule cells, and fixed macrophages (Roberts, 2001).

There is no previous study on effect the thermal agent on the histological structure of gill tissue. Therefore, this study is aimed at investigating than possibility of histological changes in the gills of Cyprinus carpio on exposure to thermal changes.

\section{MATERIALS AND METHODS}

This study is based on fish carp Cyprinus carpio L. with the mean weight of 175-200g and standard mean length of $125-140 \mathrm{~cm}$ and with age of less one year.

Samples were collected from college of agriculture and forests in University of Mosul. The test samples were brought to the laboratory and were placed in glassy pool tanks containing dechlorinated tap water and supplide with aerators and thermostat for a period of two weeks. During this period, they were fed twice daily with standard fish pellet.

The examined fish were divided into three groups (25 sample for each group). The control groups were left under normal conditions to study the normal structure of gills, while the second were exposed to high temperature up to $31^{\circ} \mathrm{C}$ and the third group were exposed to low temperature up to $18^{\circ} \mathrm{C}$ at of $24 \mathrm{~h}$ daily and for 10 days respectively. The gills of the test fishes were excised keeping the filaments and rakers intact, rinsed in normal saline, fixed in $10 \%$ formalin for about $24 \mathrm{~h}$ at $4^{\circ} \mathrm{C}$ dehydrated in an ethylalcohol series of ascending concentrations, cleared in xylene, infiltrated with paraffin at $56^{\circ} \mathrm{C}$, then embedded in paraffin wax (Luna, 1968). Thin sections of the selected gill tissues of about $4 \mu \mathrm{m}$ was cut by means of a rotatory microtome, dehydrated and stained with haematoxylin and eosin and mounted with D.P.X. The sections were examined and photomicrographs using an Olympus $\mathrm{BH}_{2}$ microscope fitted with photographic attachment were taken. The prepared slides were used to describe the normal histological structure and histological alterations in gills.

\section{RESULTS}

1- $\quad$ Treated group with high temperature:

After exposure to high temperature, the fish gills showed hyperplasia of epithelial cells in branchial secondary lamellae, congestion of blood vessels, hypertrophy of pillar cells (fig. 2). Abundance of mucous substance and hemorrhage between the branchial secondary lamellae (fig. 3) in comparison with control group (fig. 1).

2- $\quad$ Treated group with low temperature:

After exposure to low temperature, the fish gills also showed hyperplasia of epithelial cells at the bases of branchial secondary lamellae as well as shrinkage of branchial blood vessels, fusion the ends of branchial secondary lamellae, atrophy of some epithelial cells and pillar cells of branchial secondary lamellae (fig. 4), damage of some branchial secondary lamellae and lamellar disorganization (fig. 5). Some of lamellar epithelial cells becomes rounded and hemorrhage between the branchial secondary lamellae (fig. 6) in comparison with control group (fig. 1).

\section{DISCUSSION}

Environmental conditions can result in two types of structural changes in tissues of the organism. One is the result of the direct toxic effect of the pollutants leading to degeneration and necrosis. The second is a result of compensatory mechanisms that deal with 
environmental stressor as in cellular hyperplasia (Hughes and Perry, 1976). In the present case, it seems that our results are of compensatory mechanisms.

All histological lesions observed in the gills of Cyprinus carpio in this study, are categorized under lamellar cell hyperplasia and hypertrophy, cellular atrophy, bloody congestion and hemorrhage, lamellar fusion and lamellar damage, these findings could be linked with increase in the activities of the test organisms exposed to the changing environment, diffusion distance from surrounding water to capillaries and at the some time an increase in the amount of tissue (blood corpuscles) in the blood spaces of secondary lamellae and this fact agreed with the opinion of (Olojo et al., 2005; Antonio et al., 2007; Ayoola 2008a and b).

Under high temperature, cellular hyperplasia and hypertrophy were an important feature. Cells are principally derived from the primary lamellae, they migrate distally, resulting in an accumulation of cells at the leading edge of the secondary lamellae, known colloquially as (clubbing) of lamellae (Roberts, 2001). As a result, this alterations could contribute to an increase in the diffusion distance from surrounding water to capillaries and simultaneously increase in the amount of tissue in the secondary lamellae and impair the diffusion of oxygen through the swollen epithelium (Bhagwant and Elahee, 2002). This result is in line with the submission of (Wedemeyer et al., 1990; Ayoola, 2008a).

Moreover, the gills showed bloody congestion, where, some changes in blood vessels may also occur, when fishes suffer a more severe type of stress. In this case, damaged pillar cells can result in an increased blood flow inside the lamellae, causing dilation of the marginal channel, bloody congestion or even an eneurysm (Takashima and Hibiya, 1995; RosetyRodriguez et al., 2002; Martinez et al., 2004).

The rupture of the gill epithelium could cause heamorrhage, this lesion can be interpreted as areflection of the direct action of the thermal agent on the tissue (Temmink et al, 1983). The presence of mucous-filled cavity observed in the gill filaments of Cyprinus carpio may be considered as an ion trap to concentrate trace elements from surrounding water and favour cell adhesion between the neighbouring secondary lamellae (Tao et al., 2000). It may as well serve to protect the epithelia against both mechanical abrasion and infection as suggested by Olson and Fromm (1973).

Under low temperature, the gills shows close similarity to lesions brought about by high temperature specially lamellaer cell hyperplasia and hemorrhage between the branchial secondary lamellae, as well as the presence of partial fusion of some secondary lamellae, which is example of defense mechanism (Camargo and Martinez, 2007), and may have been protective in that they could diminish the vulnerable gill surface area (Richmonds and Dutta, 1989; Takashima and Hibiya, 1995). Secondary lamellar fusion may take place as an ultimate result of massive lamellar hyperplasia causing a solid fusion of many or all of the lamellar capillaries within amass of hyperplastic epithelium. However, usually, the level of proliferation is less, but because of changes in the consistency of the mucous with loss of surfactant properties, individual secondary lamellae may adhere focally, to produce alamellar complex. This response occurs with a number of stimuli such as with protozoan parasite infections (Goldes et al., 1988), also with chronic aluminum effects in (acid rain) toxicity in brown trout (Karlsson-Norrgren et al., 1986 a and b) and with reduced temperature as in present study. On the other hand, shrinkage of branchial blood vessels and cellular atrophy, this lesions might be due to unfavourable environmental conditions such as 
reduced water level, and comparatively low oxygen content associated with low water temperature (Chandra, 1987).

Damage done to the some branchial secondary lamellae may be indicated that the reduced temperature caused impairment in gaseous exchange efficiency of the gills (Hossam and Fagr., 2007; Ayoola, 2008a and b).

In conclusion the present study showed that histopathology is a useful biomarker for environmental contamination. These responses indicate that physical alterations were severe enough to lead to structural changes at the tissue level,specially when elevating and reducing of water temperature.

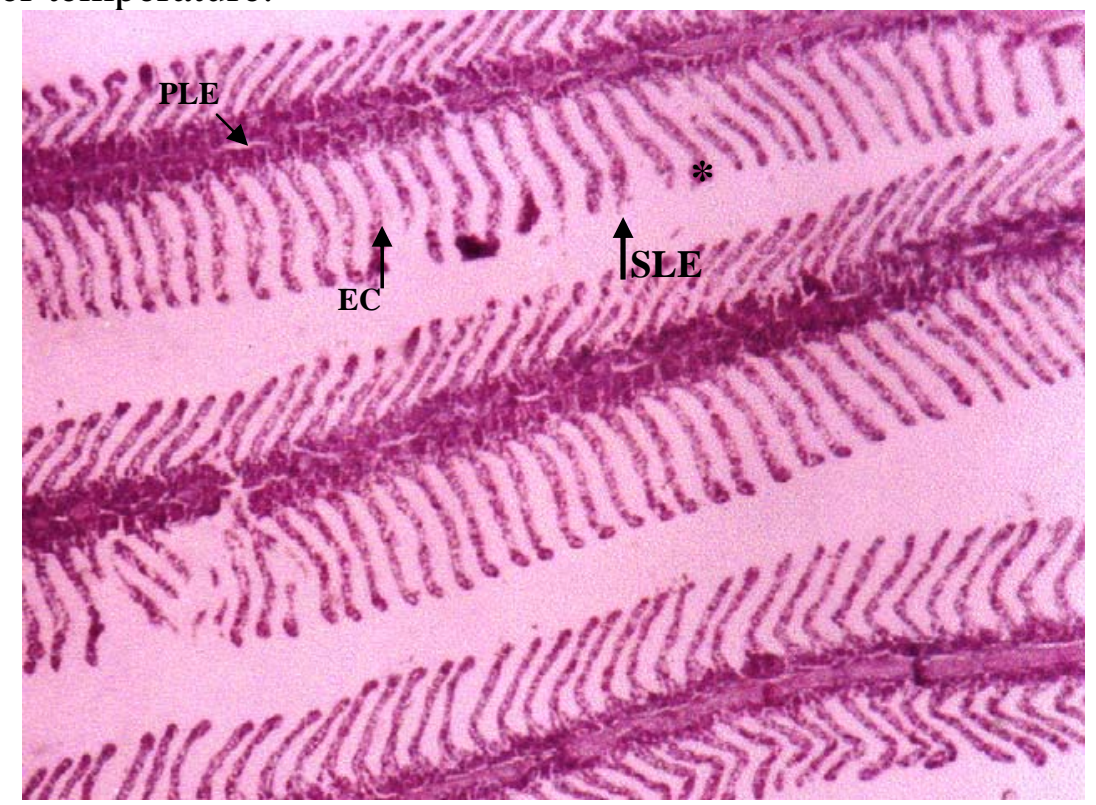

Fig. 1: Section from control fish gill showing primary lamellae (PLE), Secondary Lamellae (SLE), epithelial cells (EC), and water channel (*). X100. H \& E

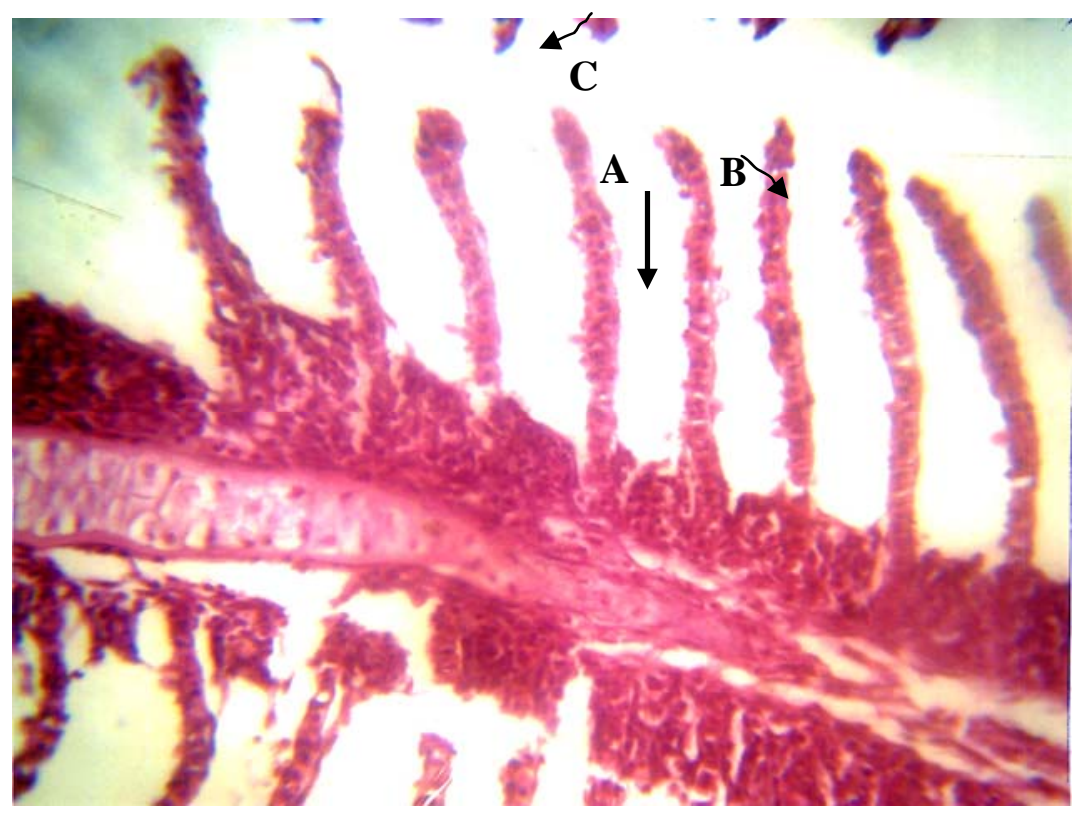

Fig. 2: Section from fish gill treated with high temperature showing hyperplasia of the epithelial cells (A), hypertrophy of the pillar cells (B) and blood congestion (C)-X400 H \& F. 


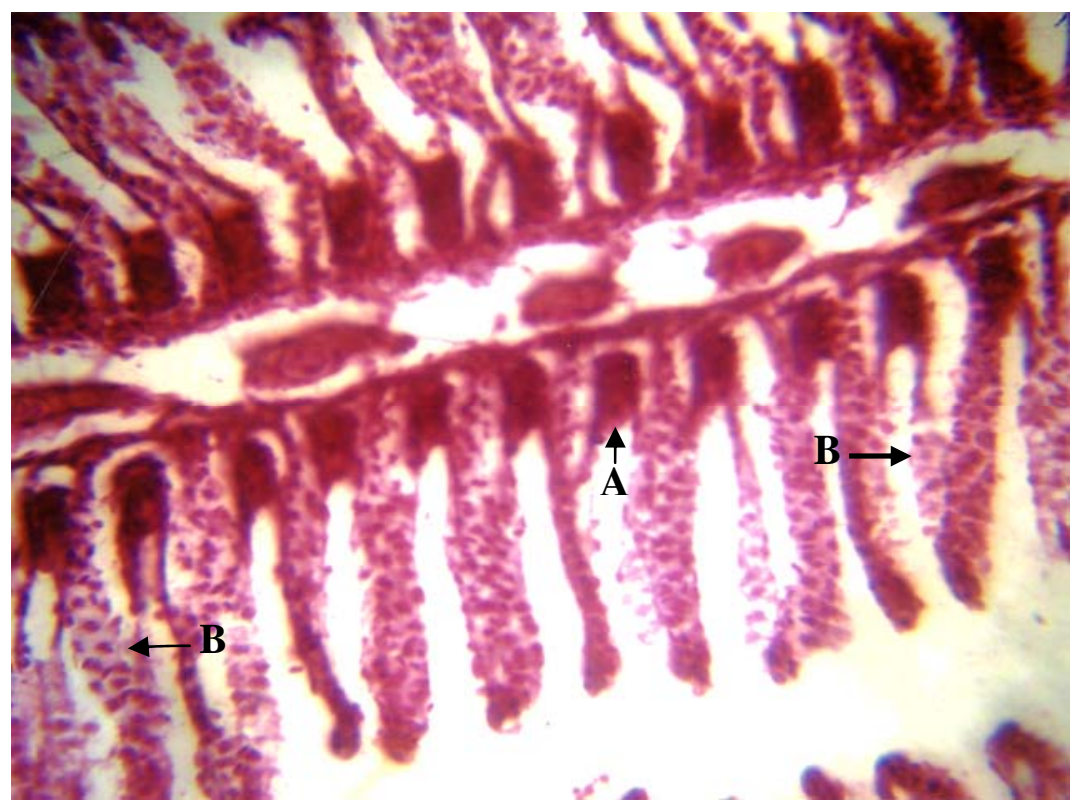

Fig. 3: Section from fish gill treated with high temperature showing abundance of mucous substance (A) and epithelium rupture with hemorrhage (B). X400. H \& E.

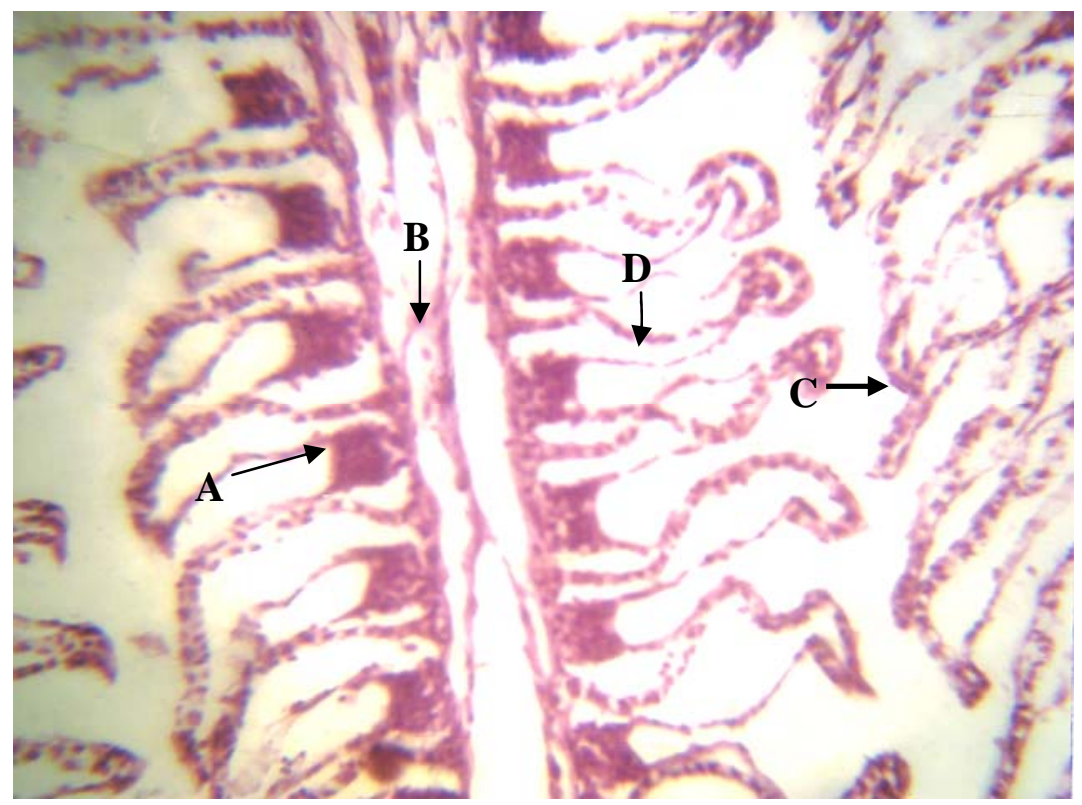

Fig. 4: Section from fish gill treated with low temperature showing hyperplasia of the epithelial cell between the bases of secondary lamellae (A), shrinkage of blood vessels (B), fusion the ends of secondary lamellae (C) and cellular atrophy (D). X400. H \& E. 


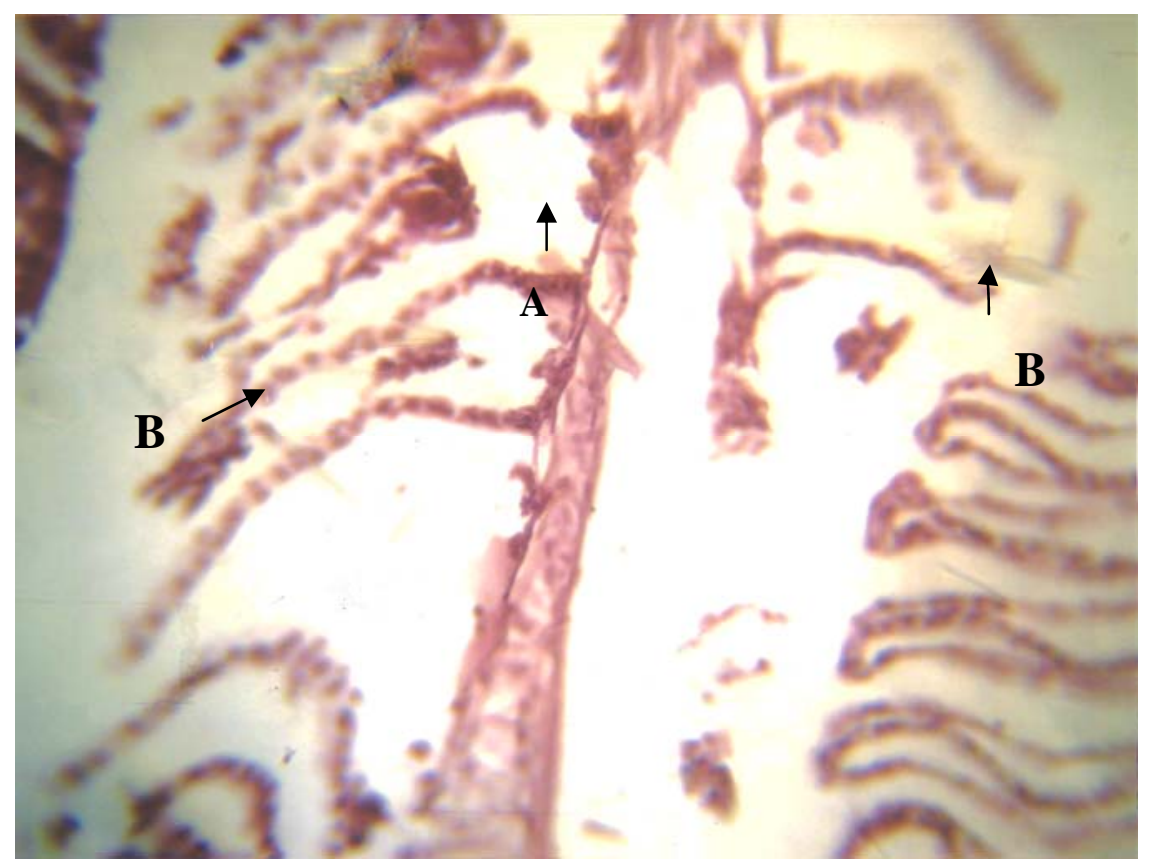

Fig. 5: Section from fish gill treated with low temperature showing damage of some secondary lamellae (A) and lamellar disorganization (B). X400. H \& E.

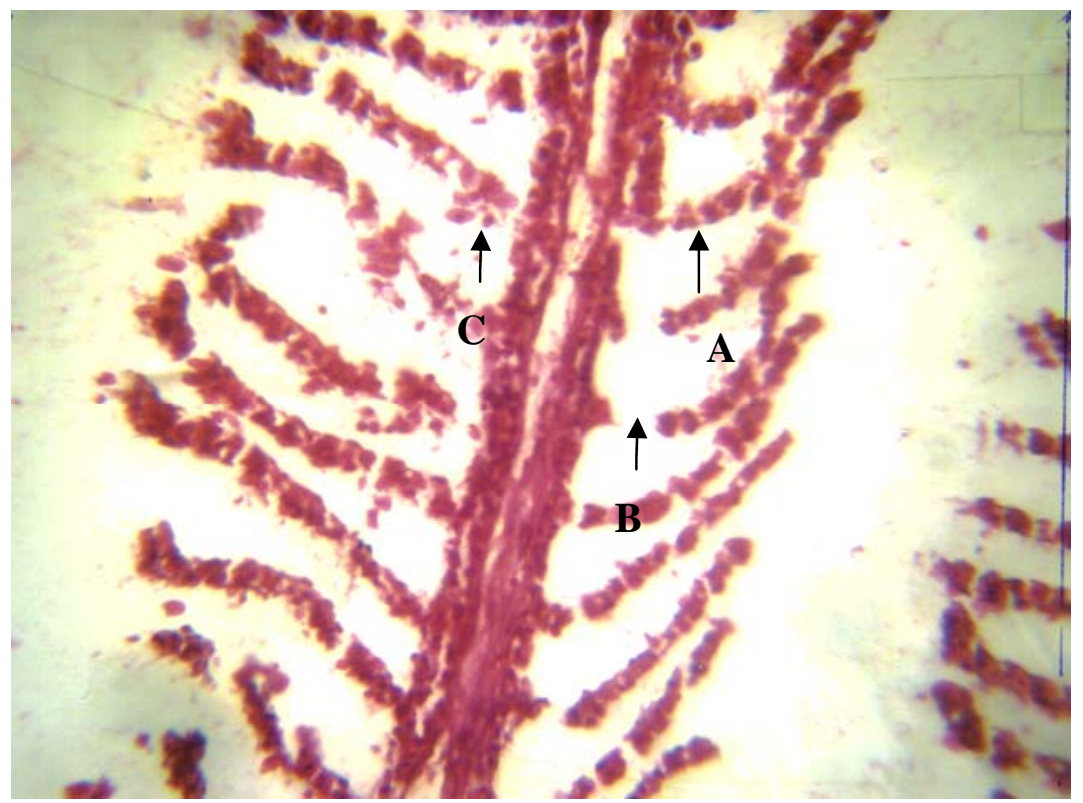

Fig. 6: Section from fish gill treated with low temperature showing rounded epithelial cells (A), damage of secondary lamellae (B) and hemorrhage (C). X400. H \& E. 


\section{REFERENCES}

Al-Hamdani, A. H. A.; Al-Taee, S.K.T. (2009). Effect thermal stress on fish Carassius auratus. Basra J. Veter. Sear. 8(2), 52-55 (In Arabic).

Antonio, F.F.; Jorge, V.F.C.; Sofia, G. S.; Sandra, M.M.; Joao, C.; Pedro, M. (2007). Histophathological changes in liver and gills epithelium of Nile tilapia, Oreochromis niloticus, exposed to waterborne copper. Pesq. Vet. Bars. Marco. 27(3), 103-109.

Awal, M. A.; Begum, A.A.; Chandra, K.J.; Ahmed, G.U.; Kurohmaru, M. (2001). Myxosporidin infection of gills and skin among carp from nursery ponds in Bangladesh histopathology. Vet. Arhiv, 71(5), 265-276.

Ayoola, S. O. (2008a). Histopathological effects of glyphosate on juvenile African catfish (Clarias gariepinus) Ameri-surasian . J. Agric. Environ. Sci. 4(3), 362-367.

Ayoola, S.O. (2008b). Toxicity of glyphosate herbicides on Nile tilapia (Oreochromis niloticus) juvenile. Afr. J. Agric. Res. 3(2), 825-834.

Bhagwant, S.; Elahee, K.B. (2002). Pathologic gill lesions in two edible lagoon fish species, Mulloidichthys flavolineatus and Mugil cephalus, from the bay of poudre d'or, Mauritius. Western Indian Ocean. J. Mar. Sci. 1 (1), 35-42.

Camargo, M.M.P.; Martinez, C.B.R. (2007). Histopathology of gills, kidney and liver of a Neotropical fish caged in an urban stream. Neotropical Ichthyology, 5(3), 327-336.

Cerqueira, C.C.C.; Fernandes, M.N. (2002). Gill tissue recovery after cooper exposure and blood parameter responses in the tropical fish Prochilodus scrofa. Ecotoxicol. and Environ. Safety, 52, 83-91.

Chandra, K.J. (1987). Fish health monitoring and control of disease. In training manual of training on integrated farming to the upazila fisheries officer. DOF, Bang. 1, 155.

Coutinho, C.; Gokhale, K. S. (2000). Selected oxidative enzymes and histopathological changes in the gills of Cyprinus carpio and Oreochromis mossambicus cultured in seconfdary sewage effluent. Water Research. 34, 2997-3004.

Crespo, S.; Sala, R. (1986). Ultrastructural alterations of the dogfish (Scyliorhinus canicula) gill filament related to experimental aquaticzinc pollution. Dis. Aquat. Org. 1, 99104.

Engelhardt, F.R.; Wong, M.P.; Duey, M.E. (1981). Hydromineral balance and gill morphology in rainbow trout Salmo gairdenri, acclimated to fresh and sea water as affected by petroleum exposure. Aquatic Toxicol. 1, 175-186.

Fernandes, M.N.; Mazon, A.F. (2003). Environmental Pollution and fish gill morphology. In: Val, A.L. and Kapoor, B.G. (Eds). Fish adaptation. Enfield, Science Publishers: 203-231.

Goldes, S. A.; Ferguson, H.W.; Moccia, R.D.; Daoust, P. Y. (1988). Histological effects of the inert suspended clay kaolin on the gills of juvenile rainbow trout, Salmo gairdneri. Richardson. J. Fish Dis., 11, 23-34.

Hossam, H. A.; Fagr, K.A. (2007). Study on the aspect of hexavalent chromium on some biochemical, cytotoxicological and histopathological aspects of the oreochromis spp. Pakistan J. Biol. Sci. 10(22), 3973-3982.

Hughes, G.M.; Perry, S.F. (1976). Morphometric study of trout gills: A light microscope method for the evaluation of pollutant action. J. Exp. Biol. 63, 447-460. 
Karlsson-Norrgren, L.; Björklund, I.; Ljungberg, O.; Runn, P. (1986b). Acid water and aluminium exposure: experimentally induced gill lesions in brown trout, Salmo trutta L. J. Fish Dis., 9, 11-26.

Karlsson-Norrgren, L.; Dickson, W.; Ljungberg, O.; Runn, P. (1986a). Acid water and aluminium exposure: gill lesions and alumunuium accumulation in farmed brown trout, Salmo trutta L. J. Fish Dis., 9, 1-10.

Korai, A.K.; Lashari, K.H.; Sahato, G.A.; Kazi, T.G. (2010). Histological lesions in gills of feral cyprinids, related to the uptake of waterborne toxicants from Keenjhar lake. Fish Biol. 18, 157-176.

Leino, R. L.; McCormick, H. (1984). Morphological and morphometrical changes in chloride cell of the gills of Pimephales prolelas after chloride exposure to acid water. Cell tissue Res. 236, 121-128.

Lemke, A.E.; Mount, D.I. (1963). Some effect of alkylbenzene sulfonate in the blue gill, Lepomis macrochirus. Trans. Am. Fish. Soc. 92, 372-378.

Luna, L.G. (1968). "Manual of Histology Staining Methods of the Armed Forces Institute of Pathology". Migraw-Hillbukoc; New York, 3rd edn. pp. 258.

Martinez, C.B.R.; Nagae, M.Y.; Zaia, C.T.B.V.; Zaia, D.A.M. (2004). Morphological and physiological acute effects of lead in the neotropical fish Prochilodus lineatus. Brazilian J. of Biol., 64(4), 797-807.

Mazon, A.F.; Pinheiro, G. H. D. Fernandes, M.N. (2002). Hematological and physiological changes induced by short-term exposure to copper in the freshwater fish, Prochilodus scrofa. Brazilian J. of Biol., 62 (4A), 621-631.

Nowak, B. (1992). Histological changes in gills induced by residue of endosulfan, Aquat. Toxicol. 23, 63-84.

Ogundiran, M.A.; Fawole, O.O.; Adewoya, S.O.; Ayandiran, T. A. (2009). Pathologic lesions in the gills of Clarias gariepinus exposed to sublethal concentrations of soap and detergent effluents. J. Cell and Animal Biol . 3(5), 78-82.

Oliveira Ribeiro, C. A.; Pelletier, E.; Pfeiffer, W. C.; Rouleau, C. (2000). Comparative uptake, bioaccumulation, and gill damages of inorganic mercury in tropical and nordic freshwater fish. Environ. Res. 83, 286-292.

Olojo, A.A.; Olurin, K.B.; Mbaka, G.; Oluwemimo, A.D. (2005). Histopathology of gills and liver tissues of the African catfish Calrias gariepinus exposed to lead. Afr. $J$. Biotech. 4(1), 117-122.

Olson, K. R.; Fromm, P.O. (1973). Ascanning electron microscopic study of secondary lamellae and chloride cells of rainbow trout (Salmo gairdneri). Z. Zellforsch. 143, 439-449.

Peters, G.; Hoffmann, R.; Klinger, H. (1984). Environmental induced gill disease of cultured rainbow trout (Salmo gairdneri). Aquaculture. 38, 105-126.

Peters, G.; Hong, D. Q. (1985). "Gill Structure and Blood Electrolyte Levers of European Eels Under Stress in A.E.Ellis (Ed) Fish and Shellfish Pathology". Academic Press, London, pp. 183-198.

Poleksic, V.; Mitrovic-Tutundzic, V. (1994)."Fish gills as a monitor of sublethal and chronic effects of pollution". pp. 339-352. In: Müller, R. and R. Lioyd (Eds). Sublethal and chronic effects of pollutants on freshwater fish. Oxford, Fishing New Books. 
Richmonds, C.; Dutta, H.M. (1989). Histopathological changes induced by malathion in the gills of blue gill Lepomis macrochirus. Bull Environ. Contam. Toxicol. 43, 123-30.

Risburg, S. B.; Bastide, J. (1995). Hepatic perturbations induced by a Herbicide (Antrazine) in juvenile grey mullet Liza ramada (Mugilidae telosei): an ultrastructural study. Aquat. Toxicol. 31, 217-229.

Roberts, R.J. (2001). "Fish Pathology". The anatomy and physiology of teleosts. China, 3rd edn. pp. 65-69.

Rosety - Rodrigueiz, M.; Ordonez, F. J.; Rosety, M.; Rosety, J. M.; Ribelles, A.; Carrasco, C. (2002). Morphohisto-chemical changes in the gills of turbot, Scophthalmus maximus L., induced by sodium dodecyl sulfate. Ecotoxicol and Environ Safety, 51, 223-228.

Sinhaseni, P.; Tesprateed, T. (1987). Histopathological effects of paraquat and gill function of Puntius gonionotus Bleeker. Bull Environ. Contam. Toxical. 38, 308-312.

Soderberg, R. W.; McGee, M. V.; Body, C. F. (1984). Histology of cultured channel catfish Icatfish punctatus (Rafinesquel). J. Fish Biol. 24: 683-690.

Solid, J.; Weber, R.E.; Nilsson, G.E. (2005). Temperature alters the respiratory surface area of crucian carp Carassius carassius and gold fish carassius auratus. J. Experim. Biol. 208, 1109-1119.

Szakolczai, J. (1997). Histopathological changes induced by environmental stress in common carp, Japanese common carp, European eel and African catfish act. Veterinaria Hungarica. 45 (1), 1-10.

Takashima, F.; Hibiya, T. (1995). "An Atlas of Fish Histology: normal and pathological features". 2nd edn. Tokyo, Kodansha.

Tao, S.; Li, H.; Li, C.S.; Lam, K.C. (2000). Fish uptake of inorganic and mucous complexes of lead. Ecotoxicol. Environ. Safe. 46, 174-180.

Tat-Sing, L.; Syed, L.S.; Nagri, M.; Cornelius, L. (1983). Toxicity of two herbicides (basegram, disqual) and on algaecide (citronellas) to mosquito fish Gambusia affinuis, Environ. Pollut. 30, 1503-1516.

Temmink, J.; Bowmieister, P.; Jong, P.; Van der Berg, J. (1983). An ultrastructural study of chromate-induced hyperplasia in the gill of rainbow trout, Salmo gairdneri. Aquatic Toxicology, 4, 165-179.

Wedemyer, G.; Barton, B. A.; McLeay, D.J. (1990). "Stress and acclimation in fishes. In: Schreck", C.B.; Moyle, P.B (eds). Methods in fish biology. Am. Fisheries Soc. Bethesda, Maryland, USA. pp. 451-489. 